\title{
Screening of Disease Incidence in Rice Cultivars against Pyricularia oryzae in Talwandi Sabo, Punjab, India
}

\author{
Nalini Singh* and Jasvir Singh Brar
}

Guru Kashi University, Sirsa-Sardulgarh Rd, Talwandi Sabo, Punjab 151302, India

*Corresponding author

\section{A B S T R A C T}

\section{Keywords}

Pyricularia oryzae, Malwa region, Rice blast, Incidence, Intensity, Rice cultivars

\section{Article Info}

Accepted:

20 July 2020

Available Online:

10 August 2020
The rice blast affects the leaves on which it causes diamond-shaped white to gray or reddish-brown lesions with reddish to brown borders. In this paper, authors have identified the rice blast caused by Pyricularia oryzae using five rice cultivars growing in Malwa region of Punjab and study the incidence and intensity of leaf, neck and panicle blast of rice. The surveillance was carried on tillering and around flowering stages. The highest leaf blast and incidence was $80.0 \%, 19.0 \%$ recorded, whereas the lowest was $21.0 \%, 14.0 \%$ observed. The rice blast shows the occurrence for the disease having the ideal predisposing conditions.

\section{Introduction}

Rice (Oryza sativa) is one of the most important cereal crops in India as in area, production and productivity. Almost $90 \%$ of the rice is grown and consumed in Asia (1). A Rice blast caused by Pyricularia oryzae Cavara synonym Pyricularia grisea Sacc. The anamorph of Magnaporthe grisea (Herbert), is one of the most destructive and wide spread disease (2). This disease has caused significant yield losses in many rice growing countries e.g. $75 \%$ loss grains in India (3). It affect all above ground parts of a rice plant leaf, collar, node, neck, parts of panicle and some time leaf sheath. Paddy Blast identify by initial symptoms appear as white greygreen lesion or spots, with dark green border. Older lesions on the leaves are elliptical or spindle shaped and whites to gray centres with red to brownish or necrotic border (4). The pathogen manifests itself at the seedling, tillering and flowering stages of crop growth causing losses on account of leaf-, node- and neck-blast in the state (5). Frequent epiphytotics of the disease in the state for the last about fifteen years have been inflicting heavy qualitative and quantitative losses to the farmers. The application of excessive nitrogenous fertilizers, low night temperature $\left(20^{\circ}-240^{\circ} \mathrm{C}\right)$, dew deposition on 
leaves $(\mathrm{RH}>90 \%)$ and water stress at panicle emergence stage have also been found to favour the disease development (6). The disease cycle of rice blast involves three distinct phases: infection (germination of conidia), colonisation of mycelium, and sporulation (7). The present study has analysed and identification of rice blast i.e. incidence and intensity.

\section{Materials and Methods}

\section{Description of the study area}

The survey was conducted during 2017/18 cropping season of one major rice growing at Talwandi Sabo, Bathinda i.e. Malwa region of Punjab. The site is South-western part of Punjab and north western India in the Malwa Region. The annual rainfall, average minimum and maximum temperature of Talwandi Sabo Bathinda is $20 \mathrm{~mm}$ to $40 \mathrm{~mm}$, $15^{\circ} \mathrm{C}$ and $45^{\circ} \mathrm{C}$, respectively.

\section{Survey of Rice Diseases}

Surveys were conducted during September and October 2017/2018 to determine the incidence and distribution of rice diseases in Talwandi Sabo, Bathinda.

\section{Disease Assessment}

During study of Rice blast (Pyricularia Oryzae), the collected symptoms from the leaf, neck and panicle regions of the plant showing the typical blast symptoms in rice growing area of Guru Kashi University, Talwandi Sabo fields during SeptemberOctober 2017 and 2018 crop seasons. The leaf blast incidence was recorded by tillering and around flowering stages assessing upper three leaves of each random tiller from field and expressed as per cent for each plot (8). The observations are on symptomatology, disease incidence and severity of disease were recorded on rice plants in the field. The data on disease severity were recorded on plants in 1 sq meter area at four corners as well as in the centre of the field. Disease severity was recorded on $0-9$ scale (IRRI 1996) as follows:

The figure 1 shows the rice blast grading as per IRRI, 1996 and used in identification of intensity and incidence in rice plant.

The method of growing of various verities of rice i.e. V1 (PR114), V2(PR126), V3(PR124), V4 (PB1121) and V5(PR122) using LSD shown in figure 2.

\section{Leaf Blast Incidence}

The lesions due to this disease appear on leaves. The tips of leaf lesions are typically spindle-shaped to diamond-shaped spots, wide in the center and pointed at the ends (Figure 3). In table 1, the Leaf Blast Incidence was recorded by assessing upper three leaves of each random tiller from each of the ten random hills from each field and expressed as per cent for each location (5).

Disease incidence $(\%)=\frac{\text { No of diseased leaves } \times 100}{\text { Total no-leaves assessed }}$

\section{Leaf Blast Intensity}

The Leaf Blast Intensity was calculated using the following formula:

$\frac{\text { Leaf }}{\frac{\text { BnWx100 }}{\text { Bxmaximum grade value }}}$ Intensity $(\mathrm{LBI})(\%)=$

Where

PDI $=$ Per cent disease intensity

$\mathrm{V}=$ Disease score

$\mathrm{n}=$ Number of leaves showing a particular score

$\mathrm{N}=$ Total number of leaves 
examined/assessed

\section{Neck Blast Incidence}

One random tiller from each of the ten hills in each field was assessed for the neck blast (figure 4) and expressed as per cent. Neck blast incidence was calculated using the following formula:

\section{Neck Blast Incidence $(\%)=$}

No. of panicles with severe neck blast $x 100$ Total no. of panicles observed per location

\section{Neck Blast Intensity}

The extent of neck blast was further quantified by scoring it using the following scale (Table 2). Neck blast intensity was calculated using the following formula:

Neck $\underset{\sum \mathbf{n} v \times 100}{\text { Blast }}$ Intensity $\quad(\mathrm{NBI})(\%)=$ Normaximum grade value

Where

$\mathrm{V}=$ Disease score

$\mathrm{n}=$ Number of panicles showing a particular score

$\mathrm{N}=$ Total number of panicles examined

\section{Panicle blast}

Panicle blast causes direct yield losses, since filling of the grains on infected panicles is poor at best in figure 5. For this reason, and because panicle blast occurs late in the season when the farmer has invested all of his production inputs for the crop, panicle blast is the more serious phase of the blast disease (10). The previous studies to estimate yield loss due to panicle blast have shown that panicle blast incidence may be linearly related to yield loss, using simple empirical damage functions. Comparison of the various studies show that the estimated yield loss ranged from 0.4 to $1.0 \%$ per percent infected panicles (11).

\section{Statistical analyses}

Data from both trials were subjected to an analysis of variance (ANOVA) to determine the significance of incidence and intensity by the SPSS. The experimental repeats were analysed separately. The least significant difference (LSD) was performed for the mean comparison when varietal differences were found to be significant. We have used F-test for analysis the above rice blast disease that is based f-distribution and used to compare the variance of the two independent samples. This is also used in the context of analysis of variance (ANOVA) for judging the significance of more than two sample means at one and the same time. It is also used for judging the significance of multiple correlation coefficients (Ume 9 - Issue 3 • 1000135).

\section{Results and Discussion}

An intensive stratified surveillance of paddy growing in Guru Kashi University farm, five rice varieties viz., PR114, PR 124, PR 126,PR 122, PB 1121 cultivars revealed that the disease occurred in proportions during all the cropping seasons with maximum leaf blast incidence recorded in cultivar PR 114 is $80.0 \%$ and minimum in PR 124 is $21.0 \%$, respectively. In Table 3 and Figure, the results revealed that the overall mean leaf blast incidence in all the five rice cultivars during 2017- 2018 varied $38.2 \%$ and $36.2 \%$, respectively. the highest mean Neck blast incidence in PR 124 is $19.0 \%$ and minimum in PR 126 is $14.0 \%$.whereas the pooled neck blast incidence during 2017and 2018 was $18.4 \%$ and $15.2 \%$, respectively. The average panicle blast incidence is maximum in PB1121 and minimum in PR 122 is 52.5 and 
35.5 , respectively. the pooled mean of panicle blast in both year is ranged from 36.3 and 37,0 respectively (Table 3 ). The overall rice blast symptoms in five cultivars most susceptible is PR114 and moderately resistant PB1121.

From table 4, the disease incidence affected mean Rice Blast Scores, F $(2,12)=3.38$, $\mathrm{p}=.07$ at using alpha $=0.5$. Our hypothesis is that the Rice blast mean is equal to disease intensity. P ("sig") $=0.12$ for 2017 and P ("sig") $=0.07$ for 2018 , both way are greater than 0.05 so we have accepted these hypotheses. The different disease incidence account for $36 \%$ of the variance in the rice blast score. This is the effect size as indicated by partial Eta squared.

Table.1 Leaf blast score description (9)

\begin{tabular}{|c|c|c|}
\hline Disease rating & Description & Host Behaviour \\
\hline 0 & No lesion observed & Highly Resistant \\
\hline 1 & Small brown specks of pin point size & Resistant \\
\hline 2 & $\begin{array}{l}\text { Small roundish to slightly elongated, necrotic gray spots, about } \\
1-2 \mathrm{~mm} \text { in diameter, with a distinct brown margin. Lesions are } \\
\text { mostly found on the lower leaves }\end{array}$ & $\begin{array}{l}\text { Moderately } \\
\text { Resistant }\end{array}$ \\
\hline 3 & $\begin{array}{c}\text { Lesion type same as in 2, but significant number of lesions on } \\
\text { the upper leaves }\end{array}$ & $\begin{array}{l}\text { Moderately } \\
\text { Resistant }\end{array}$ \\
\hline 4 & $\begin{array}{c}\text { Typical susceptible blast lesions, } 3 \mathrm{~mm} \text { or longer infecting less } \\
\text { than } 4 \text { per cent of leaf area }\end{array}$ & $\begin{array}{l}\text { Moderately } \\
\text { Susceptible }\end{array}$ \\
\hline 5 & $\begin{array}{l}\text { Typical susceptible blast lesions of } 3 \mathrm{~mm} \text { or longer infecting } 4- \\
10 \text { per cent of the leaf area }\end{array}$ & $\begin{array}{l}\text { Moderately } \\
\text { Susceptible }\end{array}$ \\
\hline 6 & $\begin{array}{l}\text { Typical susceptible blast lesions of } 3 \mathrm{~mm} \text { or longer infecting } 11- \\
25 \text { per cent of the leaf area }\end{array}$ & Susceptible \\
\hline 7 & $\begin{array}{l}\text { Typical susceptible blast lesions of } 3 \mathrm{~mm} \text { or longer infecting } 26- \\
50 \text { per cent of the leaf area }\end{array}$ & Susceptible \\
\hline 8 & $\begin{array}{l}\text { Typical susceptible blast lesions of } 3 \mathrm{~mm} \text { or longer infecting } 51- \\
75 \text { per cent of the leaf area and many leaves are dead }\end{array}$ & $\begin{array}{l}\text { Highly } \\
\text { Susceptible }\end{array}$ \\
\hline 9 & $\begin{array}{c}\text { Typical susceptible blast lesions infecting }>75 \text { per cent of the } \\
\text { leaf area and many leaves dead }\end{array}$ & $\begin{array}{c}\text { Highly } \\
\text { Susceptible }\end{array}$ \\
\hline
\end{tabular}

Table.2 Neck Blast Score description (9)

\begin{tabular}{|c|c|}
\hline Disease rating & Description \\
\hline $\mathbf{0}$ & No visible lesions or lesions only on few pedicles \\
\hline $\mathbf{1}$ & Lesions on several pedicles or secondary branches \\
\hline $\mathbf{3}$ & $\begin{array}{c}\text { Lesions on few primary branches or the middle part of panicle axis } \\
\text { Lesions partially around the panicle base(node) or the uppermost internode } \\
\text { neck of the panicle or the lower part of the panicle axis near the base }\end{array}$ \\
\hline $\mathbf{7}$ & $\begin{array}{r}\text { Lesions completely around the panicle base or the uppermost internode or } \\
\text { panicle axis near the base with more than } 30 \% \text { of filled grain }\end{array}$ \\
\hline $\mathbf{9}$ & $\begin{array}{c}\text { Lesions completely around the panicle base or the uppermost internode or } \\
\text { panicle axis near the base with less than } 30 \% \text { of filled grain }\end{array}$ \\
\hline
\end{tabular}


Table.3 Incidence of leaf and neck blast disease of rice in various cultivars during 2017-2018

\begin{tabular}{|c|c|c|c|c|c|c|c|c|c|}
\hline \multirow[t]{2}{*}{ Rice cultivars } & \multicolumn{2}{|c|}{$\begin{array}{c}\text { Leaf blast } \\
\text { incidence }(\%) *\end{array}$} & \multirow[t]{2}{*}{ Mean } & \multicolumn{2}{|c|}{$\begin{array}{c}\text { Neck blast } \\
\text { incidence }(\%)^{* *}\end{array}$} & \multirow[t]{2}{*}{ Mean } & \multicolumn{2}{|c|}{$\begin{array}{c}\text { Panicle blast } \\
\text { incidence (\%) }\end{array}$} & \multirow[t]{2}{*}{ Mean } \\
\hline & 2017 & 2018 & & 2017 & 2018 & & 2017 & 2018 & \\
\hline PR 114 & 81 & 79 & 80.0 & 22 & 15 & 18.5 & 25.5 & 26 & 38.5 \\
\hline PR 124 & 22 & 21 & 21.0 & 20 & 18 & 19.0 & 47 & 45 & 46.0 \\
\hline PR 126 & 40 & 38 & 39.0 & 15 & 13 & 14.0 & 40 & 41 & 40.5 \\
\hline PR 122 & 25 & 23 & 24.0 & 17 & 14 & 15.5 & 35 & 36 & 35.5 \\
\hline PB 1121 & 23 & 20 & 21.5 & 18 & 16 & 17.5 & 34 & 37 & 52.5 \\
\hline Over all mean & 38.2 & 36.2 & & 18.4 & 15.2 & & 36.3 & 37.0 & \\
\hline
\end{tabular}

*Average of 100 leaves taken per observation

**Average of 100 panicles taken per observation

Table.4 Tests of disease incidence of Rice Blast using ANOVA

\begin{tabular}{|c|c|c|c|c|c|c|c|c|c|}
\hline Source & $\begin{array}{l}\text { Dependent } \\
\text { Variable }\end{array}$ & $\begin{array}{l}\text { Type III } \\
\text { Sum of } \\
\text { Squares }\end{array}$ & df & $\begin{array}{l}\text { Mean } \\
\text { Square }\end{array}$ & $\begin{array}{l}\text { F- } \\
\text { ratio }\end{array}$ & Sig. & $\begin{array}{l}\text { Eta } \\
\text { Squared }\end{array}$ & $\begin{array}{l}\text { Noncent. } \\
\text { Parameter }\end{array}$ & $\begin{array}{l}\text { Observed } \\
\text { Power }\end{array}$ \\
\hline \multirow{2}{*}{$\begin{array}{l}\text { Corrected } \\
\text { Model }\end{array}$} & 2017 & 1193.43 & 2 & 596.72 & 2.57 & 0.12 & 0.30 & 5.14 & 0.42 \\
\hline & 2018 & 1528.13 & 2 & 764.07 & 3.38 & 0.07 & 0.36 & 6.75 & 0.52 \\
\hline \multirow[t]{2}{*}{ Intercept } & 2017 & 14384.02 & 1 & 14384.02 & 62.00 & 0.00 & 0.84 & 62.00 & 1.00 \\
\hline & 2018 & 13024.27 & 1 & 13024.27 & 57.55 & 0.00 & 0.83 & 57.55 & 1.00 \\
\hline \multirow[t]{2}{*}{ DISEASE } & 2017 & 1193.43 & 2 & 596.72 & 2.57 & 0.12 & 0.30 & 5.14 & 0.42 \\
\hline & 2018 & 1528.13 & 2 & 764.07 & 3.38 & 0.07 & 0.36 & 6.75 & 0.52 \\
\hline \multirow[t]{2}{*}{ Error } & 2017 & 2783.80 & 12 & 231.98 & & & & & \\
\hline & 2018 & 2715.60 & 12 & 226.30 & & & & & \\
\hline \multirow[t]{2}{*}{ Total } & 2017 & 18361.25 & 15 & & & & & & \\
\hline & 2018 & 17268.00 & 15 & & & & & & \\
\hline \multirow{2}{*}{$\begin{array}{l}\text { Corrected } \\
\text { Total }\end{array}$} & 2017 & 3977.23 & 14 & & & & & & \\
\hline & 2018 & 4243.733 & 14 & & & & & & \\
\hline \multicolumn{10}{|c|}{ a Computed using alpha $=.05$} \\
\hline \multicolumn{10}{|c|}{ b $\quad$ R Squared $=.300($ Adjusted R Squared $=.183)$} \\
\hline \multicolumn{10}{|c|}{ c $\quad$ R Squared $=.360($ Adjusted R Squared $=.253)$} \\
\hline
\end{tabular}


Table.5 Multiple Comparisons using LSD

\begin{tabular}{|c|c|c|c|c|c|c|c|}
\hline \multirow{3}{*}{$\begin{array}{c}\text { Dependent } \\
\text { Variable } \\
2017\end{array}$} & \multirow{2}{*}{\multicolumn{2}{|c|}{$\begin{array}{l}\text { Incidence } \\
\text { (I) and (J) }\end{array}$}} & \multirow{3}{*}{$\begin{array}{c}\text { Mean Difference } \\
\text { (I-J) }\end{array}$} & \multirow{3}{*}{$\begin{array}{c}\text { Std. } \\
\text { Error } \\
9.633\end{array}$} & \multirow{3}{*}{$\begin{array}{l}\text { Sig. } \\
0.062\end{array}$} & \multicolumn{2}{|c|}{ 95\% Confidence Interval } \\
\hline & & & & & & \multirow{2}{*}{$\begin{array}{c}\text { Lower Bound } \\
-1.188\end{array}$} & \multirow{2}{*}{$\begin{array}{c}\text { Upper Bound } \\
40.788\end{array}$} \\
\hline & LBI & NBI & & & & & \\
\hline & & PBI & 1.900 & 9.633 & 0.847 & -19.088 & 22.888 \\
\hline & NBI & LBI & -19.800 & 9.633 & 0.062 & -40.788 & 1.188 \\
\hline & & PBI & -17.900 & 9.633 & 0.088 & -38.888 & 3.088 \\
\hline & PBI & LBI & -1.900 & 9.633 & 0.847 & -22.888 & 19.088 \\
\hline & & NBI & 17.900 & 9.633 & 0.088 & -3.088 & 38.888 \\
\hline \multirow[t]{6}{*}{2018} & \multirow[t]{2}{*}{ LBI } & NBI & 21.000 & 9.514 & 0.048 & 0.270 & 41.730 \\
\hline & & PBI & -0.800 & 9.514 & 0.934 & -21.530 & 19.930 \\
\hline & \multirow[t]{2}{*}{ NBI } & LBI & -21.000 & 9.514 & 0.048 & -41.730 & -0.270 \\
\hline & & PBI & -21.800 & 9.514 & 0.041 & -42.530 & -1.070 \\
\hline & \multirow[t]{2}{*}{ PBI } & LBI & 0.800 & 9.514 & 0.934 & -19.930 & 21.530 \\
\hline & & NBI & 21.800 & 9.514 & 0.041 & 1.070 & 42.530 \\
\hline \multicolumn{8}{|c|}{ Based on observed means. The error term is Error. } \\
\hline & & & & & & & \\
\hline
\end{tabular}

Table.6 Intensity of leaf and neck blast and panicle in rice cultivar during 2017-18

\begin{tabular}{|c|c|c|c|c|c|c|c|c|c|}
\hline \multirow[t]{2}{*}{ Rice cultivar } & \multicolumn{2}{|c|}{$\begin{array}{c}\text { Leaf blast } \\
\text { intensity }(\%) *\end{array}$} & \multirow[t]{2}{*}{ Mean } & \multicolumn{2}{|c|}{$\begin{array}{c}\text { Neck blast intensity } \\
(\%)^{* *}\end{array}$} & \multirow[t]{2}{*}{ Mean } & \multicolumn{2}{|c|}{$\begin{array}{c}\text { Panicle blast } \\
\text { intensity }(\%)\end{array}$} & \multirow[t]{2}{*}{ Mean } \\
\hline & 2017 & 2018 & & 2017 & 2018 & & 2017 & 2018 & \\
\hline PR 114 & 11 & 19 & 15 & 2 & 1.5 & 1.75 & 3 & 4 & 3.5 \\
\hline PR 124 & 12 & 11 & 11 & 3 & 1.8 & 2.4 & 4 & 3.4 & 3.7 \\
\hline PR 126 & 10 & 13 & 11.5 & 5 & 1.3 & 3.15 & 3.5 & 4 & 3.75 \\
\hline PR 122 & 15 & 12 & 13.5 & 3.7 & 4 & 3.85 & 2.5 & 3 & 2.75 \\
\hline PB 1121 & 13 & 11 & 12 & 2.8 & 2.6 & 2.7 & 2 & 2.7 & 2.35 \\
\hline $\begin{array}{c}\text { Over all } \\
\text { mean }\end{array}$ & 12.2 & 13 & 12.6 & 3.3 & 2.24 & 2.77 & 3 & 3.42 & 3.21 \\
\hline
\end{tabular}

*Figures based on observations on 300 leaves

**Figures based on observations on 100 panicles 
Table.7 Tests of between-subjects effects of intensity

\begin{tabular}{|c|c|c|c|c|c|c|c|c|c|}
\hline Source & $\begin{array}{l}\text { Dependent } \\
\text { Variable }\end{array}$ & $\begin{array}{l}\text { Type III Sum of } \\
\text { Squares }\end{array}$ & df & $\begin{array}{l}\text { Mean } \\
\text { Square }\end{array}$ & $\mathbf{F}$ & Sig. & $\begin{array}{c}\text { Eta } \\
\text { Squared }\end{array}$ & $\begin{array}{l}\text { Noncent. } \\
\text { Parameter }\end{array}$ & $\begin{array}{c}\text { Observed } \\
\text { Power }\end{array}$ \\
\hline \multirow{2}{*}{$\begin{array}{l}\text { Corrected } \\
\text { Model }\end{array}$} & 2017 & 273.233 & 2 & 136.617 & 73.253 & 0.000 & 0.924 & 146.506 & 1.000 \\
\hline & 2018 & 361.937 & 2 & 180.969 & 42.564 & 0.000 & 0.876 & 85.128 & 1.000 \\
\hline \multirow[t]{2}{*}{ Intercept } & 2017 & 570.417 & 1 & 570.417 & 305.853 & 0.000 & 0.962 & 305.853 & 1.000 \\
\hline & 2018 & 592.833 & 1 & 592.833 & 139.435 & 0.000 & 0.921 & 139.435 & 1.000 \\
\hline \multirow[t]{2}{*}{ INTENSITY } & 2017 & 273.233 & 2 & 136.617 & 73.253 & 0.000 & 0.924 & 146.506 & 1.000 \\
\hline & 2018 & 361.937 & 2 & 180.969 & 42.564 & 0.000 & 0.876 & 85.128 & 1.000 \\
\hline \multirow[t]{2}{*}{ Error } & 2017 & 22.380 & 12 & 1.865 & & & & & \\
\hline & 2018 & 51.020 & 12 & 4.252 & & & & & \\
\hline \multirow[t]{2}{*}{ Total } & 2017 & 866.030 & 15 & & & & & & \\
\hline & 2018 & 1005.790 & 15 & & & & & & \\
\hline \multirow{2}{*}{$\begin{array}{l}\text { Corrected } \\
\text { Total }\end{array}$} & 2017 & 295.613 & 14 & & & & & & \\
\hline & 2018 & 412.957 & 14 & & & & & & \\
\hline \multicolumn{10}{|c|}{ a Computed using alpha $=.05$} \\
\hline \multicolumn{10}{|c|}{ b R Squared = .924 (Adjusted R Squared = .912) } \\
\hline \multicolumn{10}{|c|}{ c R Squared $=.876($ Adjusted R Squared $=.856)$} \\
\hline
\end{tabular}

Table.8 Multiple comparisons of disease intensity in rice blast

\begin{tabular}{|c|c|c|c|c|c|c|c|}
\hline \multirow{3}{*}{$\begin{array}{l}\text { Dependent } \\
\text { Variable } \\
2017\end{array}$} & \multirow{2}{*}{\multicolumn{2}{|c|}{$\begin{array}{l}\text { INTENSITY } \\
\text { (I) AND (J) }\end{array}$}} & \multirow{3}{*}{$\begin{array}{c}\text { Mean Difference } \\
\text { (I-J) }\end{array}$} & \multirow{3}{*}{$\begin{array}{c}\text { Std. Error } \\
0.864\end{array}$} & \multirow{3}{*}{$\begin{array}{l}\text { Sig. } \\
0.000\end{array}$} & \multicolumn{2}{|c|}{ 95\% Confidence Interval } \\
\hline & & & & & & \multirow{2}{*}{$\begin{array}{c}\text { Lower Bound } \\
7.018\end{array}$} & \multirow{2}{*}{$\begin{array}{c}\text { Upper Bound } \\
10.782\end{array}$} \\
\hline & LBI & NBI & & & & & \\
\hline & & PBI & 9.200 & 0.864 & 0.000 & 7.318 & 11.082 \\
\hline & NBI & LBI & -8.900 & 0.864 & 0.000 & -10.782 & -7.018 \\
\hline & & PBI & 0.300 & 0.864 & 0.734 & -1.582 & 2.182 \\
\hline & PBI & LBI & -9.200 & 0.864 & 0.000 & -11.082 & -7.318 \\
\hline & & NBI & -0.300 & 0.864 & 0.734 & -2.182 & 1.582 \\
\hline \multirow[t]{6}{*}{2018} & LBI & NBI & 10.960 & 1.304 & 0.000 & 8.119 & 13.801 \\
\hline & & PBI & 9.780 & 1.304 & 0.000 & 6.939 & 12.621 \\
\hline & NBI & LBI & -10.960 & 1.304 & 0.000 & -13.801 & -8.119 \\
\hline & & PBI & -1.180 & 1.304 & 0.383 & -4.021 & 1.661 \\
\hline & PBI & LBI & -9.780 & 1.304 & 0.000 & -12.621 & -6.939 \\
\hline & & NBI & 1.180 & 1.304 & 0.383 & -1.661 & 4.021 \\
\hline
\end{tabular}


Fig.1 Grading of Rice Blast (0-9) as per IRRI, 1996

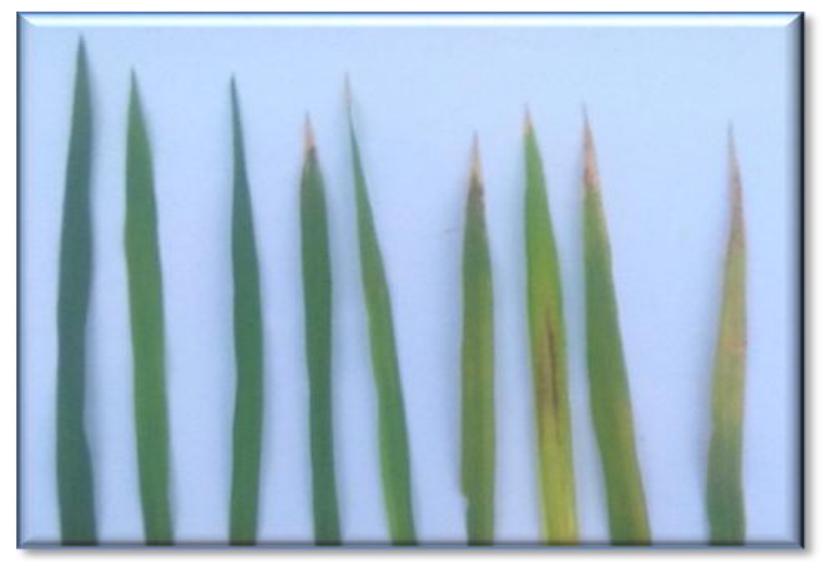

Fig.2 Latin Square Design (LSD) used in field with various rice cultivars

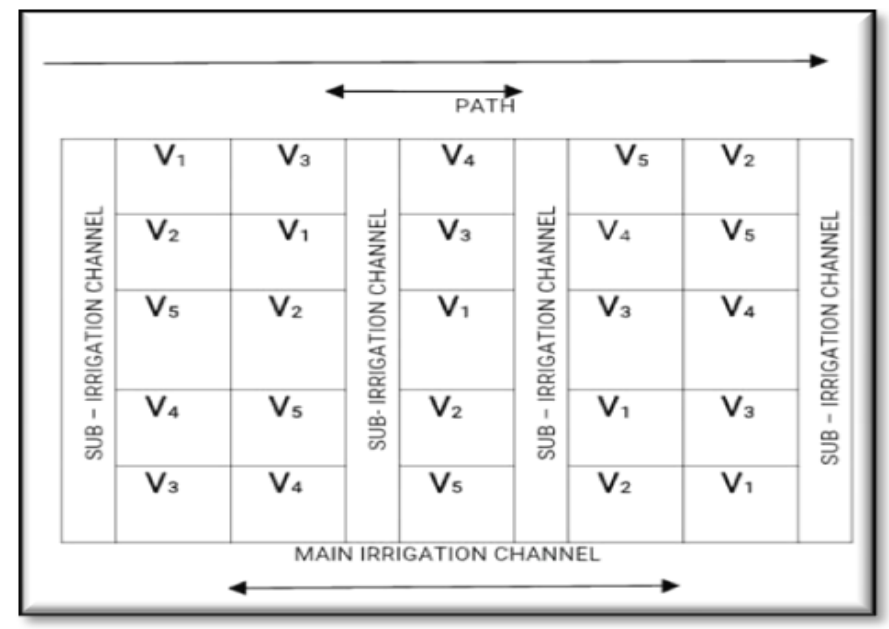

Fig.3 Leaf blast on the upper leaf surface and field of rice

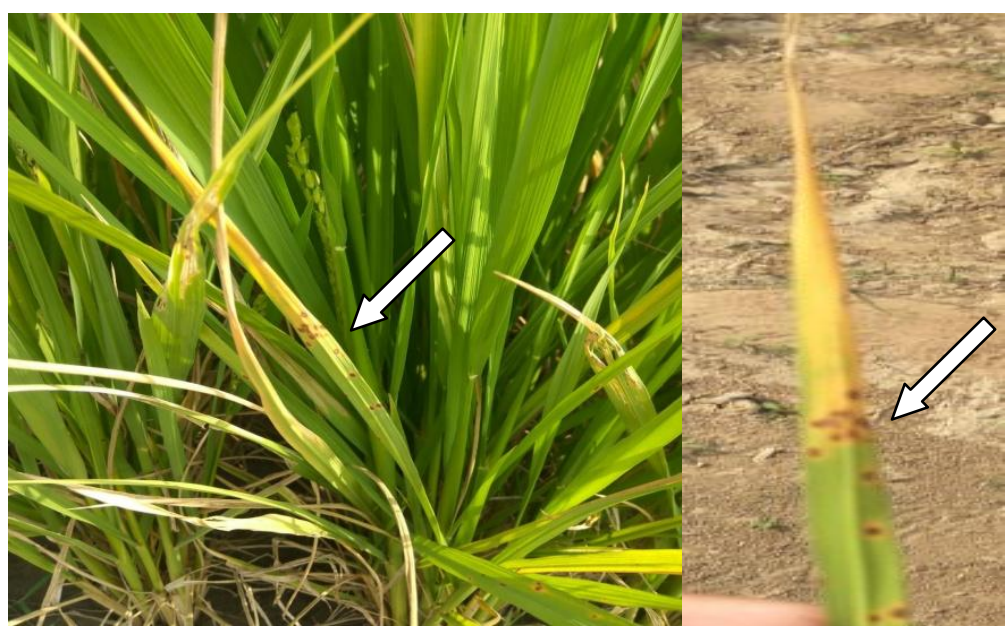


Fig.4 Neck blast on the lower surface neck and field of rice

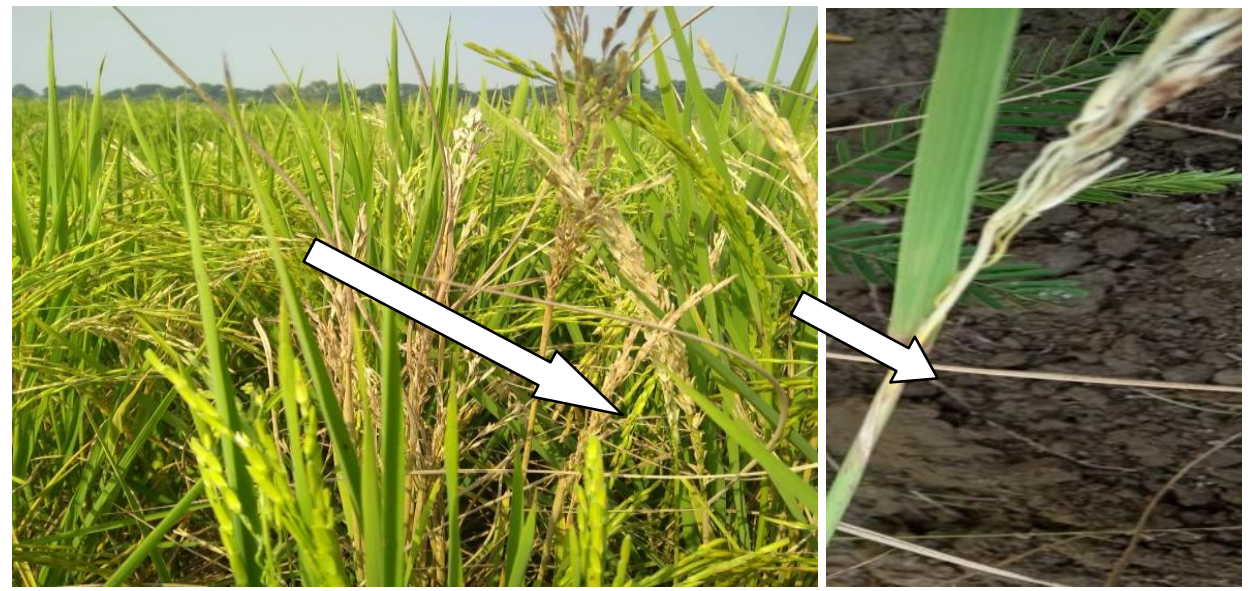

Fig.5 Symtoms of panicle blast on the panicle rice

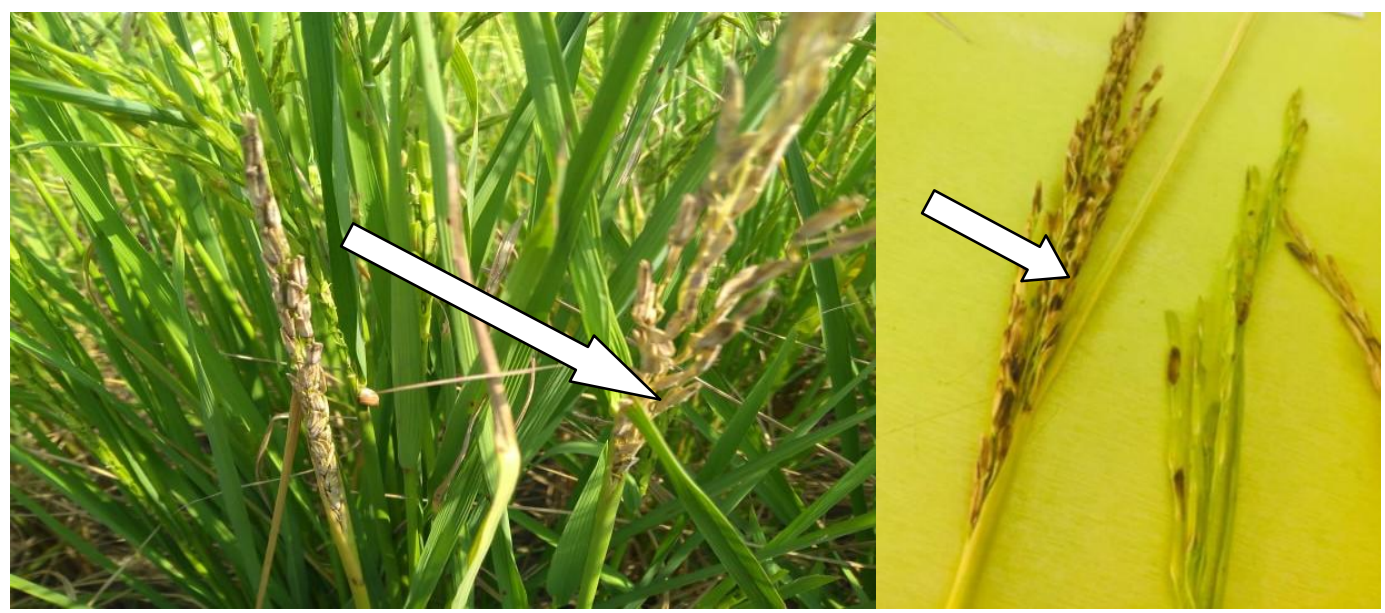

Fig.6 Incidence of leaf and neck blast disease of rice in various cultivar during 2017-2018

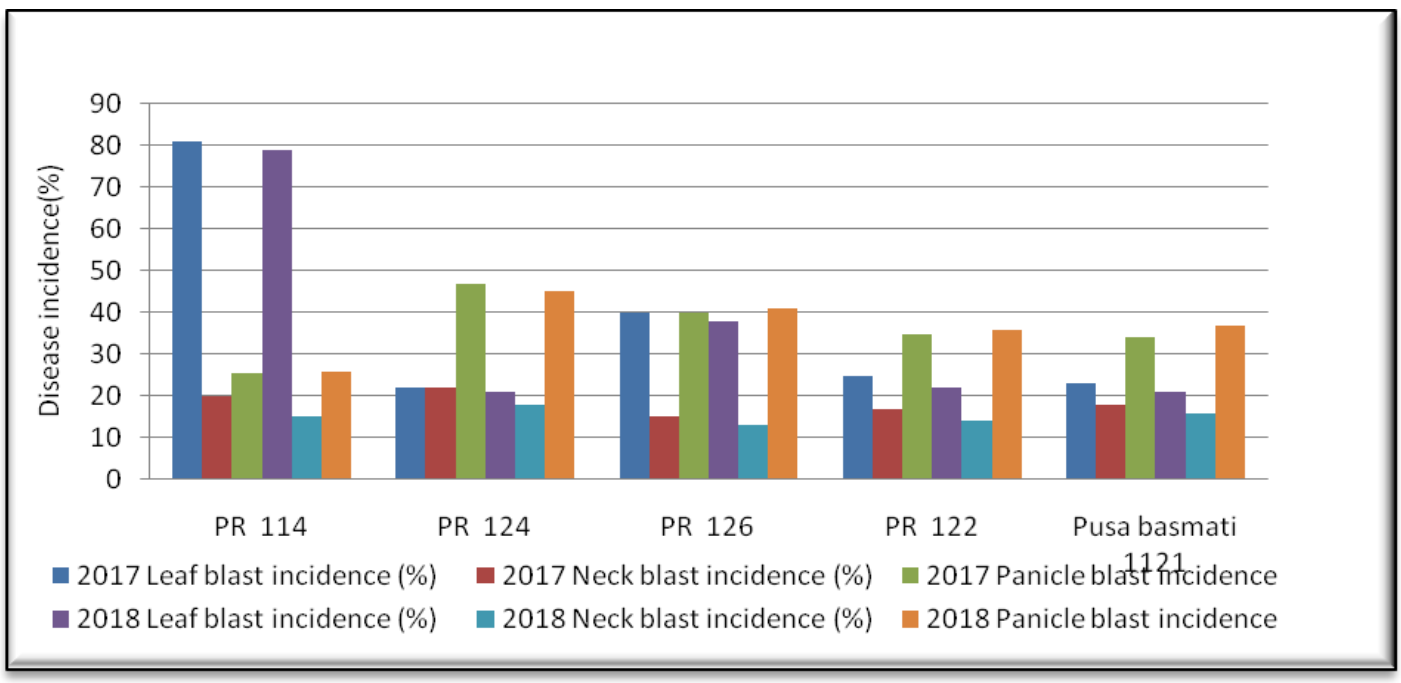


Fig.7 Intensity of leaf and neck blast and panicle in rice cultivar during 2017-18

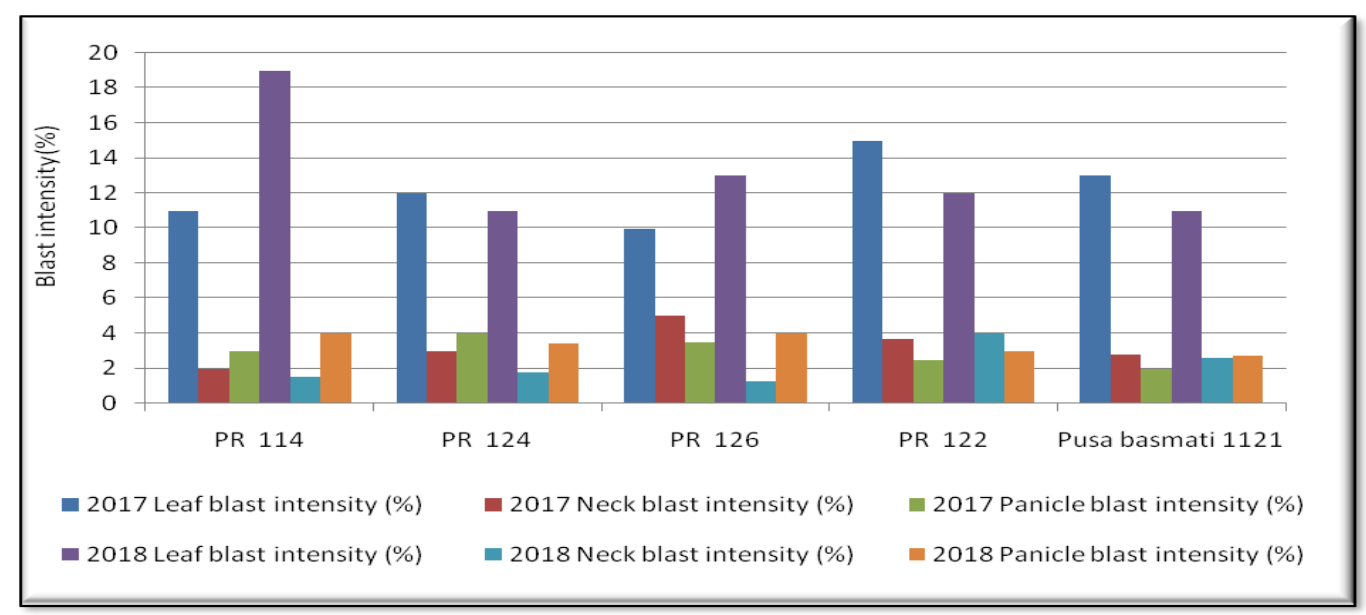

The table 5 shows that PBI with NBI is significantly rejected because here $\mathrm{P}<0.05$ from data of rice blast 2018 and NBI with LBI is significantly accepted because her $\mathrm{P}>$ 0.05 from data of rice blast data 2017 .

In Table 6 and Figure 4, the highest leaf blast intensity $15 \%$ was observed PR114 followed by PR124 (11\%) during 2017and 2018. The pooled leaf blast intensity during the years 2017 and 2018 was $12.2 \%$, and $13.0 \%$ respectively, with a pooled mean of $20.03 \%$. The average neck blast intensity ranged from $3.3 \%$ to $2.24 \%$ during 2017 and 2018 . The highest neck blast intensity was $4.00 \%$ recorded in PR124 and 1.3\% in PR 126. The highest panicle blast intensity $(3.75 \%)$ was observed in PR 126 whereas the lowest neck blast incidence $(2.35 \%)$ was recorded in $\mathrm{PB}$ 1121. The pooled panicle blast incidence during 2017 and 2018 was 3.42 and 3.21 per cent, respectively.

From table 7 , the disease intensity affected mean Rice Blast Scores, F $(2,12)=42.564$, $\mathrm{p}=.00$ at using alpha $=0.5$. Our hypothesis is that the Rice blast mean is equal to disease intensity. P ("sig") $=0.00$ for 2017 and P ("sig") $=0.00$ for 2018 , both way are less than 0.05 so we have reject these hypotheses. The different disease intensity account for $87.6 \%$ of the variance in the rice blast score. This is the effect size as indicated by partial Eta squared.

The table 8 shows that PBI with NBI is significantly accepted because here $\mathrm{P}>0.05$ from data of rice blast 2018 and NBI with LBI is significantly rejected because her $\mathrm{P}<0.05$ from data of rice blast data 2017.

In conclusion this paper, authors have identified the rice blast caused by Pyricularia oryzae using five rice cultivars growing in Malwa region of Punjab and study the incidence and intensity of leaf, neck and panicle parts of rice. The surveillance was carried on tillering and around flowering stages. The highest neck blast intensity was $4.83 \%$ recorded, whereas the lowest was $1.3 \%$ observed. The highest leaf and neck blast incidence of $81.02 \%$ and $19.36 \%$ was observed in cultivar PR114, whereas it was the lowest $(18.33 \%$ and $1.03 \%)$ in cultivar Pusa1121. The rice blast shows the occurrence for the disease having the ideal predisposing conditions. The different disease incidence account for $36 \%$ of the variance in the rice blast score. The different disease intensity account for $87.6 \%$ of the variance in the rice blast score. Moreover, the future research direction should be against rice blast 
disease with high incidence and intensity (i.e leaf blast, neck blast and panicle blast). Research on this regard should be considered to increase the quantitative and qualitative production of rice.

\section{References}

1.Khush, G.S. And Brar, D.S., (2002). Biotechnology for rice breeding: progress and potential impact. In: proceeding of the 20th session of the international rice commission (23th 26th July, 2002, Bangkok, Thailand)

2.Jia, Y., Me Adams, S.A., Bryan, G.T., Hershay, H.P. and B. Valent (2000). Direct interaction of resistance genes products confers rice blast resistance. Embo. J. 19: 4004 - 4014.

3.Padmanabhan SY, Chakrabarti NK, Mathur SC, Veeraraghavan S (1970) Identification of pathogenic races of Pyricularia oryzae in India. Phytopathology 60: 1574-1577.

4.Ramesh Singh Yadav and Amit Kumar Yadav. (2018). Development of Blast Disease Management Modules for Minimization of Tricycazole in Basmati Rice. Int.J.Curr.Microbiol.App.Sci. $\quad 7(10)$ :
777-781

5.Kapadiya IB, Akbari LF, Siddhapara MR, Undhad SV (2013) Evaluation of fungicides and herbicides against the sheath blight of rice. The Bioscan 8: 433-436

6.Dodan, D.S. and Ram Singh (1995). Effect of planting time on the incidence of blast and false smut of rice in Haryana. Indian Phytopathol. 48: 185186

7.Chowdhury MD, Riton K, Vinodsattar A, Brahmachari K (2014) Studies on the water use efficiency and nutrient uptake by rice under system of intensification. The Bioscan 9: 85-88.

8.Mackill DJ, Bonman JM (1992) Inheritance of blast resistance in near isogenic lines of rice. Phytopathology 82: 746749.

9.Goto I (1965a) Plant insect and disease survey. Special Report 18: 132.

10.Ziegler R S, Leong S A, Teng P S (Eds.) Rice blast disease. CAB International, Wallingford Oxon OX10 8DE, UK.

11.Ou SH, Ayad MR (1970) Pathogenic races of pyricularia oryzae originating from single lesions and monoconidial cultures. Phytopathology 58: 179-182.

\section{How to cite this article:}

Nalini Singh and Jasvir Singh Brar. 2020. Screening of Disease Incidence in Rice Cultivars against Pyricularia oryzae in Talwandi Sabo, Punjab, India. Int.J.Curr.Microbiol.App.Sci. 9(08): 2198-2208. doi: https://doi.org/10.20546/ijcmas.2020.908.251 